35. Zvity, vidomosti pro suspilno-politychne ta ekonomichne stanovyshche parafii Mykulynetskoho, Naraivskoho, Novoselskoho, Novostrilyshchanskoho, Ozirnianskoho i Oleskoho dekanativ dlia shematyzmu na 1944 r. [Reports, information on the socio-political and economic situation of parishes of the Mykulynetsky, Narayevsky, Novoselsky, Novostrilyshchansky, Ozirnia and Oles'ka deanships for the report of 1944]. TDIAL. (Tsentralnyi derzhavnyi istorychnyi arkhiv u m. Lviv). F. 201. Op. 1. Spr. 36.1942 r. - 1943 r. 77 [in Ukrainian].

36. TDIAL. (Tsentralnyi derzhavnyi istorychnyi arkhiv u m. Lviv). F. 201. Op. 1. Spr. 41. Zvity, vidomosti pro suspilno-politychne ta ekonomichne stanovyshche parafii Univskoho, Khodorivskoho, Shchyretskoho, Yanivskoho i Yarychivskoho dekanativ dlia shematyzmu na $1944 \mathrm{r}$. [Reports, information on the socio-political and economic situation of the parishes of the Univsky, Khodorovsky, Shchyretsky, Yanivsky and Yarichiv deanships for the report of 1944]. 1941 r. - 1943 r. 70 [in Ukrainian].

УДК 94 (477) «19/20»

DOI https://doi.org/10.31470/2518-7732-2019-1(15)-31-37

\section{Фігурний Юрій,}

кандидат історичних наук, доцент кафедри історії та культури України ukr.etnolog_fus@ukr.net, https//orcid.org/0000-0002-6463-0920 Державний вищий навчальний заклад «Переяслав-Хмельницький державний педагогічний університет імені Григорія Сковороди», м. Переяслав-Хмельницький, вул. Сухомлинського, 30, Київська обл., Україна, 08401

\section{Fihurnyi Yuriy,}

Candidate of Historical Sciences, Assistant Professor of the Department of History and Culture of Ukraine, ukr.etnolog_fus@ukr.net, https//orcid.org/0000-0002-6463-0920

Pereiaslav-Khmelnytskyi Hryhorii

Skovoroda State Pedagogical University, 30, Sukhomlynsky Str., Pereiaslav-Khmelnytskyi, Kyiv region, 08401, Ukraine

\title{
Перебіг неоголошеного російсько-українського військового конфлікту: мілітарні, дипломатичні та геополітичні чинники
}

У дослідженні аналізуються передумови, перебіг й сучасні суспільно-політичні наслідки агресї Російської Федерачії проти України та української нації, які мають ознаки не лите прямого й прихованого, але й міждержавного конфлікту $i$ навіть, ичивілізаційного протистояння. У статті застосовано порівняльноісторичний, історико-типологічний, ретроспективний та інші методи. Доведено щзо, євроатлантичній спільноті треба не задовольнятися меморандумами про мир і порозуміння з РФ, а розпочати активно реагувати на російськоукраӥнську війну. Для цььго їм потрібно, принаймні: 1) змінити напрямок політики щзодо порушників міжнародних домовленостей та не потурати агресору, а швидко його карати; 2) реформувати НАТО у контексті сучасних геополітичних і геостратегічних викликів та особливостей гібридного протистояння; 3) посилити інформаційну безпеку та успішно протидіяти тотальній фейковій пропаганді й кібератакам з боку РФ; 4) блискавично реагувати на порушення кордонів як членів НАТО, так $і$ крайн СС й асоційованих з ними держав (таких, як Україна), яких можна по праву віднести до європейської иивілізації. Проаналізувавши російську військову й інформаиійну агресію супроти украӥнців та сучасні суспільно-політичні наслідки війни на сході й півдні Украӥни у 2014-2019 рр., можна дійти висновку, що це не звичайне збройне протистояння за землі, природні ресурси, населення тощо, а цивілізаційний конфлікт. Зрештою, якщзо його вчасно не зупинити, він може призвести до Третьої світової війни. Незважаючи на кількісну та якісну перевагу агресора, Украӥна зупинила збройне вторгнення нападників.

Ключові слова: Украӥна, українці, Збройні Сили Украӥни, Російська Федерація, ияивілізаційна війна, військова та інформаиійна агресія Росії.

\section{The course of the undeclared Russian-Ukrainian military conflict: militaristic, diplomatic and geopolitical factors}

The study analyzes the preconditions, course and contemporary socio-political consequences of the aggression of the Russian Federation against Ukraine and the Ukrainian nation, which has signs of not only direct and covert, but also inter-state conflict and even civilizational confrontation. The research uses comparative-historical, historical-typological, retrospective and other methods. Proved that, the Euro-Atlantic community must not be content with the memorandums of peace and understanding with the Russian Federation, and begin to actively respond to the Russian-Ukrainian war. To do this, they need, at least: 1) to change the direction of policy towards violators of international agreements and not to 
condescend to the aggressor, but to punish him quickly; 2) reforming NATO in the context of current geopolitical and geostrategic challenges and the peculiarities of hybrid confrontation; 3) to strengthen information security and successfully counteract the total fake propaganda and cyber attacks from the $R F$; 4) respond lightly to the violation of the borders of both NATO members and the EU and Associated States (such as Ukraine), which can be rightly attributed to European civilization. Thus, after analyzing Russian military and informational aggression against Ukrainians and the contemporary sociopolitical consequences of the war in the east and south of Ukraine in 2014-2019, one can conclude that this is not an ordinary armed confrontation over land, natural resources, population, etc., and civilizational conflict. In the end, if it is not stopped in time, it can lead to the Third World War. Despite the quantitative and qualitative advantage of the aggressor, Ukraine stopped armed invasion of the attackers.

Key words: Ukraine, Ukrainians, the Armed Forces of Ukraine, the Russian Federation, civilization war, the militaristic and informational Russian aggression.

At the breakthrough of 2013-2014, Ukraine was experiencing difficult times. Due to the shortsighted domestic and foreign policy of the then authorities, protest actions began in Kyiv, which later grew into the Revolution of Dignity. Revolutionary protests have captured almost all regions of Ukraine and led to the escape of Viktor Yanukovych and his immediate neighbors. During reformatting of power structures the Ukrainian state was extremely weakened. Its weakness was taken by the northeastern neighbor, the so-called «brotherly» Russian Federation. At first, the aggressor captured the Crimean peninsula, and then, with the help of its agents, destabilized the situation in the east and south of Ukraine, and somewhat subsequently launched an armed invasion of Ukraine.

The urgency of the study of this problem is that by analyzing and comprehending the armed and informational Russian aggression against Ukraine and the modern social consequences of the war in eastern Ukraine, we have the opportunity to briefly analyze the preconditions, course and possible measures of the Ukrainian authorities to restore the territorial integrity of the Ukrainian state. The scientific novelty of the work is to address the important problems of contemporary Ukrainian history, namely, the Russian-Ukrainian armed and informational confrontation, the study and analysis of which is just beginning, and since this conflict is not yet complete, its final comprehension is delayed indefinitely.

During the reign of the pro-Russian government in Ukraine, domestic authorities gradually surrendered national interests, and turned the state into a Little Russian protectorate of the Russian Federation. However, the Revolution of Dignity crossed out all plans of Russian powers, so they reoriented on the power solution of the so-called «Ukrainian question», namely, the gradual weakening of Ukraine, dismemberment and final the elimination of Ukrainian statehood, the destruction of the Ukrainian nation and the absorption and full assimilation of Ukrainians.

The course of the modern Russian-Ukrainian war can be divided into the following stages: 1) the annexation of the Crimea (February-March 2014); 2) the project «Novorossiia» (April-July 2014); 3) disguised military aggression of the RF against Ukraine (July 2014 - February 2015); 4) stabilization of the front line in the east of Ukraine, permanent combat clashes in the most important areas of the confrontation and the continuous hidden military and open information aggression of the Russian Federation (February 2015 - to this day) [8, p. 20].

The annexation of Crimea has become the highest «achievement» of the Russian Federation as a whole, and Putin in particular, since the Kremlin cynically violated intergovernmental agreements and committed an act of aggression against a neighboring state. At the same time, the temporary loss of the Crimean peninsula is a defeat of the modern Ukrainian state and its then-day leadership in the RussianUkrainian confrontation. It is also necessary to separate the inaction of the Ukrainian authorities and the actions of the members of the Armed Forces of Ukraine who were loyal oaths and executed an order that prevented them from using weapons against so-called «green men».

It should be noted that the seizure of the Crimea of Russia was not a spontaneous decision of the Kremlin, but was preparing for many years. In this regard, P. Hai-Nyzhnyk stressed: «Crimea was the only region with a rather strong pro-Russian identity and at the same time was sufficiently saturated by the Kremlin's agents and armed units of the regular Russian army. It is definitely known that the Russian invasion was preceded by an active propaganda campaign, sabotage and agency activity, first of all in Sevastopol, deployed long before the start of February events directly to the special services of the Russian Federation. The main task of the Kremlin agents was the demoralization of the personnel of the Armed Forces and the encouragement of our military to refuse the armed resistance of the aggressor» [4, p. 200-201].

The loss of the Crimean peninsula and the large grouping of the Armed Forces of Ukraine in Crimea has led to a weakening of the official Kyiv on the international scene and the demoralization of Ukrainian society. Successful seizure of the Crimea pushed Putin to implement the next Novorossiya 
project, the essence of which was the dismemberment of Ukraine and the separation of the eastern and southern regions from it, with the subsequent prolongation of these destructive processes in the central, northern and western regions. Thus began the so-called «Russian Spring», which was supposed to put an end to the united Ukraine and finally destroy its cohesiveness and sovereignty.

However, in May 2014, Ukrainians took offensive, destroyed Putin's terrorists in Odessa, elected in the first round the President of Ukraine P. Poroshenko, began to create volunteer battalions and join massively the Armed Forces and the National Guard of Ukraine. In turn, the nation-elected President, with his decree, proclaimed an anti-terrorist operation and began a counter-attack on terrorist cells in eastern Ukraine. In a short time, it became clear to Putin that the «Russian Spring» had collapsed, and therefore he began unwritten armed aggression against Ukraine.

An attack on the Russian Army was a surprise to the top leadership of the Armed Forces. He led to a series of loud defeats and significant losses among servicemen and volunteers. One of them Ilovaisky boiler. At the same time, Ukrainians demonstrated the fighting spirit and military skill, which resulted in a large number of killed and wounded Russian soldiers and terrorists. In the end, the pressure of the world community and a realistic assessment of the military situation in the east of Ukraine led to the beginning of peace talks in the capital of Belarus. Thanks to the mediation of European leaders, the situation in eastern Ukraine has somewhat stabilized. At the same time, the so-called «Minsk-1» (September 2014), «Minsk-2» (February 2015) failed to radically solve the problem, they only temporarily «froze» it, as the open military conflict in the Donbass became concealed, but daily reports of killed, wounded and destroyed only confirm this terrible situation, namely the conduct of hostilities in the east of Ukraine.

P. Hai-Nyzhnyk is convinced that the so-called «Minsk agreements» were only a kind of diplomatic cover for separate talks between Russian, European and Ukrainian negotiators in order to resolve armed conflict at the price of Ukraine and Ukrainian national interests. As a result, the refusal of P. Poroshenko and his diplomatic team from Budapest, Geneva and other formats, the removal from the assistance of large geopolitical players - the United States, Great Britain, the European Union and the abandonment of Ukraine almost by itself on the Russian Federation itself. Since the mediation of France and Germany was only a cover of the compromise policy of F. Oland and A. Merkel regarding the aggressive actions (military and information) of Putin [4, p. 277-279].

In this regard, scientists in the expert-analytical report note: «The Minsk process» should be considered as a mechanism for reducing the intensity of the military component of the conflict and transfer it to the category of frozen. The distorted implementation of the «Minsk Agreements» is unprofitable for Ukraine. After all, it returns to Ukraine the ruined territories, which are completely controlled and controlled by local bandit groups and Russian occupiers, and a huge amount of an angry electorate that was washed away by Russian propaganda consciousness. Therefore, it is necessary to agree on the use of other formats, including the Norman, Geneva, or even require a return to the Budapest but updated, which will make it possible to develop more effective ways to resolve the conflict» [1, p. 25].

Despite the peacekeeping statements of diplomats, this hybrid undeclared war will continue in the future. The conflict will somewhat change its forms, but not the essence. For Putin, the war will end only when Ukraine and Ukrainians capitulate and will become an integral part of the great-power Russia and so on. «Russkagh world». For the Ukrainian state - when Russia as an imperial project disappears from the political map of the world.

We are convinced that the modern hybrid Russian-Ukrainian war is not an ordinary armed interstate confrontation over the earth, natural resources, population, etc., but is nothing else (as the scholar L. Zalizniak remarked) as a civilizational conflict [5, p. 5]. In order to understand the essence of the civilizational confrontation on the territory of Ukraine at the beginning of the twenty-first century. between democratic Europe and authoritarian Russia, one should know well the history of their relationship. Europe was not always «democratic», but it was democracy, liberal-market, and universal Christian values that helped transform this western Eurasia region into a locomotive for the development of human civilization.

In contrast, the Russian centralized state was based on the principles of a «wild» Asian mode of production, the main elements of which are monopolization, the privatization of all spheres of life, and the concentration of all power in one's hands [5, p. 122-142]. It was thanks to these system-forming factors that the small Moscow principality eventually became a huge Russian empire, and eventually in the USSR with a huge number of satellites around the world. These phantom imperial totalitarian memories of greatness and geopolitical dominance are fueled by the revanchist sentiments of Putin and 
his followers. Therefore, it is doomed to be the battlefield between European and Eurasian civilizations, as long as Russia exists in the format of the de jure federation, and de facto empires.

In turn, the fundamental differences in the ethnic, state-building, nation-building and ethnocultural traditions of Ukrainians and Russians have been, are and will be the source of a permanent RussianUkrainian confrontation. This civilization conflict will last until the victory of one of the conflicting forces. Therefore, Ukrainians need to adjust to a long-lasting confrontation with the north-eastern aggressor.

The best defender of Ukraine and Ukrainians is not the international memorandums, treaties, pacts and agreements, but the Armed Forces. Only the Ukrainian army is a reliable guarantor of the Ukrainian Self-Assembly.

The state Allies can betray, and a patriotic, professional, well-motivated Ukrainian national army will always be guarded by Ukrainian statehood. For almost 23 years, the Armed Forces of Ukraine was deliberately destroyed, decomposed, robbed and trapped, but the time came for testing, and Ukrainian troops and volunteers stopped the enemy in bulk and continued to hold the eastern front. Therefore, the Ukrainian army should be sufficiently financed, re-armed, reformed and Ukrainianized. In our opinion, there should be only five privileged and most highly paid professions in the society: military servicemen, law enforcement officers, scientists, doctors and educators, not top officials, people's deputies of the Verkhovna Rada of Ukraine or judges of all instances, etc.

One of the main factors of the cardinal renewal of the Armed Forces is the domestic militaryindustrial complex. It was Ukraine at the time of totalitarianism that was one of the largest centers of the Soviet military-industrial complex. After the disintegration of the USSR, difficult times for the Ukrainian military-industrial complex came. Despite these hardships, Ukraine has been in the top ten exporters of arms and military equipment for about 20 years. But all this was not the development of its military-industrial complex, but its stagnation and degradation (since it existed at the expense of Soviet technology and the sale of old military reserves).

In the end, the time has come for radical changes and updates. We fully agree with P. HaiNyzhnyk, that Ukraine must restore, modernize and strengthen the military-industrial complex as soon as possible, transfer it to modern innovative technologies, start production of not only defensive, but also offensive weapons [3, p. 41].

In the end, this revolutionary update of the Armed Forces and the military-industrial complex will help Ukraine to become a potential regional leader in the near future after defeating Russia into a powerful world power.

Only a legal, democratic, innovative, prosperous state can guarantee Ukraine's and Ukrainians' progressive development, preservation of Ukrainian identity and geopolitical subjectivity. Unfortunately, at present, the Ukrainian state is clan-oligarchic, and therefore needs urgent reform. For a quarter century of its modern development, Ukraine has turned into a quasi-state with a clan-oligarchic economy and administration, a typical poor country of the so-called. "Third World", which is doomed only to impoverishment and extinction. If the oligarchs and their supporters are satisfied with this situation, then the vast majority of Ukrainians, and especially their passionate share, do not satisfy this state of affairs. Therefore, this inability to overcome the difficult legacy of colonialism and totalitarianism by evolutionary way led to the emergence of revolutionary preconditions. In the end, anti-Kuchma appearances in 2000-2002, the Orange Revolution of 2004-2005 are the peculiar preparatory stages that led to a revolutionary breakthrough in the 2013-2014 biennium-the Ukrainian National Revolution of the early twenty-first century.

The time that came to pass after the conclusion of EuroMaydan, as Y. Potapenko rightly pointed out, clearly demonstrated: the oligarchic corrupt system does not dare to dismantle the new government, as well as to undertake radical reforms and lustration. In his opinion, the Revolution of Dignity and the attempts of individual oligarchs to expand their own wealth and influence as much as possible after the revolutionary events revealed the apparent impossibility to build modern European democracy and an effective economy in Ukraine without the determined and final displacement of the oligarchs from the planning and implementation of state policy [6, p. 98-99].

At the same time, the modern Russian-Ukrainian war is not a classical military conflict with the declaration of war, the transfer of the national economy to military rails, the mobilization of all available resources, the continuous front of combat operations, etc., and a hybrid confrontation, when soldiers without recognizable signs capture («squeeze») huge territories, between diplomats do not stop diplomatic, political, economic, cultural ties and at the same time there is an active information war and permanent open and hidden armed suites Ivy with a possible full-scale escalation of the military conflict. Such a hybrid war can last a long time. Therefore, Ukrainians must constantly support the 
combat readiness of their troops, control the Eastern (Donbas) and Southern (Crimea) external fronts and go on an internal offensive - eliminate the oligarch, overcome the consequences of totalitarianism, colonialism and preserve and develop the identity of Ukrainians.

Almost all of the conquerors (except for the Lithuanians of the time of the existence of the Grand Duchy of Lithuania), who once ruled on the Ukrainian ethnic lands, sought not only to conquer Ukrainians, but eventually absorb them. To this end, they planted their language, culture, traditions, customs, faith, etc. The greatest ethnic-cultural discrimination experienced by Ukrainians in the Soviet era. With the restoration of Ukrainian statehood, the ethnocultural renaissance began, but very quickly it stopped and stagnation processes began. Despite the fierce offensive by the ideologue of the concept of «Russian world» and globalization, the indifference of corrupt authorities and ordinary citizens, conscious Ukrainians managed to preserve and somewhat expand the use of their native language and respect for ethno-cultural traditions.

The «Russian world» as a politico-ideological concept is not an ordinary cultural project, but a neo-imperial geopolitical ideological doctrine that aims to not only substantiate theoretically and help to virtually reintegrate Russia as a superstate at the borders of 1914 but also eliminate it. Ukrainian statehood and the Ukrainian nation [2, p. 424].

Symbolically, the aggressor captured only those areas where the Russian language and post-Soviet Erzat culture (so-called «scoop») dominated undividedly. Therefore, Ukrainians must continue to preserve and develop (qualitatively and quantitatively) the ethno-cultural component of national culture $[8,9]$.

In connection with the active assault on Ukraine by the imperial ideologue «Russian world» there is an urgent need for the development of comprehensive Ukrainization. Under Ukrainianization, we mean the consistent activity of the state, aimed at the development of Ukrainian-centric ideology in all spheres of society - politics, economy, culture, education, science, army, police, etc [7, p. 132].

Thus, Ukrainization is not only a mechanical, one-dimensional displacement of the Russian language from all realms and the replacement of it with Ukrainian. First of all, Ukrainization must become a generally accepted and official ideological policy, an ideological basis of the state, and an effective means to overcome the consequences of Russian colonialism, Soviet totalitarianism and Putin's imperialism, and the preservation and development of the native language, culture, traditions, customs, mentality and identity of Ukrainians [8, p. 35].

For a long time, Europe was in a comfortable state - peace and harmony on the continent (the collapse of Yugoslavia and the Balkan wars became only a temporary «ugly misunderstanding»). But with the election of the President of the Russian Federation in early 2000, Putin, this state «began to rise from the knees» and, in the end, began to format the surrounding world system. Initially, this reformatted only the so-called «near abroad» (Georgia and Ukraine), later came the time and «far abroad» (Syria). The Euro-Atlantic community had the opportunity to immediately stop the revanchism and neo-imperial ambitions of the Kremlin, giving a green light at the NATO summit in Bucharest (2007) on the plan of action of Ukraine and Georgia membership in this defense alliance. However, this plan was blocked by the leading European countries, as a result of the Russian-Georgian war of 2008, the strengthening of the Russian Federation and the weakening of European civilization.

Putin made conclusions for this conflict, started military reform, rearmed the army and strengthened the informational pressure on the near and far abroad, while the Euro-Atlantic community almost ignored the beginning of the new Cold War and its gradual evolution into the «hot» stage. Anaesthesia of the Crimea of Russia caught unexpectedly by the EU and the United States. The Budapest memorandum was only a declaration of intent, and Ukraine was on its own with the aggressor. Then there were diplomatic talks, «deep concern» of our western distant and close neighbors, Minsk1, Minsk-2, meetings in the Norman format, and so on. However, this was not a fight against Russian aggression, but probably only an imitation of this struggle. It reminds us of it in 1938, when France and Great Britain tried to satisfy the predatory appetites of Germany at the price of Czechoslovakia. As a result: instead of peace, Europe received World War II. Did European leaders draw conclusions from past events? Hope that way. When the Czechs capitulated to the Nazis in 1938, the Ukrainians in 2014 fought the «rachists» and for the fourth consecutive year they held the front line.

The Euro-Atlantic community must not be content with the memorandums of peace and understanding with the Russian Federation, and begin to actively respond to the Russian-Ukrainian war. To do this, they need, at least: 1) to change the direction of policy towards violators of international agreements and not to condescend to the aggressor, but to punish him quickly; 2) reforming NATO in the context of current geopolitical and geostrategic challenges and the peculiarities of hybrid confrontation; 3) to strengthen information security and successfully counteract the total fake 
propaganda and cyber attacks from the RF; 4) respond lightly to the violation of the borders of both NATO members and the EU and Associated States (such as Ukraine), which can be rightly attributed to European civilization.

Thus, after analyzing Russian military and informational aggression against Ukrainians and the contemporary consequences of the war in the east and south of Ukraine in 2014-2019, one can conclude that this is not an ordinary armed confrontation over land, natural resources, population, etc., and civilizational conflict. In the end, if it is not stopped in time, it can lead to the Third World War. Despite the quantitative and qualitative advantage of the aggressor, Ukraine stopped armed invasion of the attackers.

\section{ДЖЕРЕЛА ТА ЛІТЕРАТУРА}

1. Агресія Російської Федерації проти України: проблеми оптимізації державного управління та системи національної безпеки. Експертно-аналітична доповідь / П. П. Гай-Нижник (керівник проекту, упоряд. і наук. ред.); авт. кол.: П. П. Гай-Нижник, Л. Л. Залізняк, І. И. Краснодемська, Ю. С. Фігурний, О. А. Чирков, Л. В. Чупрій. Київ: «МП Леся», 2016. 28 c.

2. Агресія Росії проти України: історичні передумові та сучасні виклики / П. П. Гай-Нижник (керівник проекту, упоряд. і наук. ред.); авт. кол.: П. П. Гай-Нижник, Л. Л. Залізняк, І. Й. Краснодемська, Ю. С. Фігурний, О. А. Чирков, Л. В. Чупрій. Київ: «МП Леся», 2016. $586 \mathrm{c.}$

3. Гай-Нижник П. Основні засади Стратегії деокупації та реінтеграції Криму в контексті національної безпеки України: штрихи до проблеми й напрямки розв’язання. Київ: «МП Леся», 2017. 52

4. Гай-Нижник П. П. Росія проти України (1990-2016рр.): від політики шантажу і примусу до війни на поглинання та спроби знищення. Київ: «МП Леся», 2017. 332 с.

5. Залізняк Л. Л. Україна між Сходом і Заходом. Про витоки і суть російсько-української війни 2014 р. Київ: Шлях, 2014. 168 с.

6. Потапенко Я. П’ята російсько-українська війна: від майдану до східного фронту (підходи, оцінки, інтерпретації): монографія. Переяслав-Хмельницький: «Видавництво К С В », 2016. $304 \mathrm{c}$.

7. Фігурний Ю. Роль Української національної революції початку XXI ст. в етнополітичних та етнокультурних процесах // Україна в сучасному європейському просторі в умовах зовнішньополітичних викликів: зб. наук. праць за матеріалами Міжн. наук. практ. конф., 18-19 трав. 2017 р. Переяслав-Хмельницький, 2017. С. 128-133.

8. Fihurnyi Y. Aggression of the Russian federation against Ukraine: backgrounds, course and modern social consequences. Kyiv: Small Enterprise «Lesia», 2017. 54 p.

9. Chyrkov O. Ethnic factor in the preconditions and consequences of the aggression of the Russian Federation against Ukraine / Research Institute of Ukrainian Studies. Kyiv: Small Enterprise «Lesya», 2017. 60 p.

\section{REFERENCES}

1. Hai-Nyzhnyk, P. P., Zalizniak, L. L., Krasnodemska, I. Y., Fihurnyi, Yu. S., Chyrkov, O. A., Chuprii, L. V. (2016). Ahresiia Rosiiskoi Federatsii proty Ukrainy: problemy optymizatsii derzhavnoho upravlinnia ta systemy natsionalnoi bezpeky. Ekspertno-analitychna dopovid [Aggression of the Russian Federation v. Ukraine: problems of optimization of public administration and national security system. Expert-analytical report]. Kyiv: MP Lesia [in Ukrainian]

2. Hai-Nyzhnyk, P. P., Zalizniak, L. L., Krasnodemska, I. Y., Fihurnyi, Yu. S., Chyrkov, O. A., Chuprii, L. V. (2016). Ahresiia Rosii proty Ukrainy: istorychni peredumovi ta suchasni vyklyky [Russia's Aggression Against Ukraine: Historical Background and Contemporary Challenges]. Kyiv: «MP Lesia» [in Ukrainian]

3. Hai-Nyzhnyk, P. (2017). Osnovni zasady Stratehii deokupatsii ta reintehratsii Krymu v konteksti natsionalnoi bezpeky Ukrainy: shtrykhy do problemy y napriamky rozviazannia. [The main principles of the Crimea's de-occupation and reintegration strategy in the context of Ukraine's national security: strokes to the problem and direction of the solution] Kyiv: «MP Lesia» [in Ukrainian] 
4. Hai-Nyzhnyk, P. P. (2017). Rosiia proty Ukrainy (1990-2016 rr.): vid polityky shantazhu $i$ prymusu do viiny na pohlynannia ta sproby znyshchennia. [Russia v. Ukraine (1990-2016): From the policy of blackmail and coercion to the war on absorption and attempts to destroy]. Kyiv: «MP Lesia» [in Ukrainian]

5. Zalizniak, L. L. (2014). Ukraina mizh Skhodom i Zakhodom. Pro vytoky i sut rosiisko-ukrainskoi viiny 2014 r. [Ukraine between East and West. About the origins and essence of the RussianUkrainian war of 2014]. Kyiv: Shliakh [in Ukrainian]

6. Potapenko, Ya. (2016). Piata rosiisko-ukrainska viina: vid maidanu do skhidnoho frontu (pidkhody, otsinky, interpretatsii) [Fifth Russian-Ukrainian War: from the Maidan to the Eastern Front (approaches, assessments, interpretations)] Pereiaslav-Khmelnytskyi: «Vydavnytstvo K S V» [in Ukrainian]

7. Fihurnyi, Yu. (2017). Rol Ukrainskoi natsionalnoi revoliutsii pochatku XXI st. v etnopolitychnykh ta etnokulturnykh protsesakh. [The Role of the Ukrainian National Revolution at the beginning of the twenty-first century. in ethno-political and ethnocultural processes.] Ukraina v suchasnomu yevropeiskomu prostori $v$ umovakh zovnishnopolitychnykh vyklykiv: zb. nauk. prats za materialamy Mizhn. nauk. prakt. konf.,18-19 trav. 2017 r. - Ukraine in the modern European space in the context of foreign policy challenges: sciences works on materials Int. sciences practice Conf., 18-19 May. 2017. Pereiaslav-Khmelnytskyi, 128-133. [in Ukrainian].

8. Fihurnyi, Y. (2017). Aggression of the Russian federation against Ukraine: backgrounds, course and modern social consequences. Kyiv: Small Enterprise «Lesia» [in Ukrainian].

9. Chyrkov, O. (2017). Ethnic factor in the preconditions and consequences of the aggression of the Russian Federation against Ukraine / Research Institute of Ukrainian Studies. Kyiv: Small Enterprise «Lesya» [in Ukrainian].

Одержано 1.04.2019. 